\title{
The Credit Crisis and Cycle-Proof Regulation
}

\author{
Raghuram G. Rajan
}

This article was originally presented as the Homer Jones Memorial Lecture, organized by the Federal Reserve Bank of St. Louis, St. Louis, Missouri, April 15, 2009.

Federal Reserve Bank of St. Louis Review, September/October 2009, 91(5, Part 1), pp. 397-402.

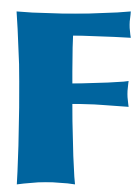
irst, I would like to thank the St. Louis Fed, especially Kevin Kliesen, and the National Association for Business Economics for inviting me to give this talk. I share with Homer Jones an affiliation with the University of Chicago. He was an important influence on Milton Friedman, and if that were all he did, he would deserve a place in history. But in addition, he was a very inquisitive economist with a reputation for thinking outside the box. He made major contributions to monetary economics. It is an honor to be asked to deliver a lecture in his name, especially at this critical time in the nation's regulatory history.

\section{WHAT CAUSED THE CRISIS?}

The current financial crisis can be blamed on many factors and even some particular players in financial markets and regulatory institutions. But in pinning the disaster on specific agents, we could miss the cause that links them all. I argue that this common cause is cyclical euphoria; and, unless we recognize this, our regulatory efforts are likely to fall far short of preventing the next crisis.

Let me start at the beginning. There is some consensus that the proximate causes of the crisis are as follows: (i) The U.S. financial sector misallocated resources to real estate, financed through the issuance of exotic new financial instruments. (ii) A significant portion of these instruments found their way, directly or indirectly, onto commercial and investment bank balance sheets. (iii) These investments were financed largely with short-term debt. (iv) The mix was potent and caused large-scale disruption in 2007. On these matters, there is broad agreement. But let us dig a little deeper.

This is a crisis born in some ways from previous financial crises. A wave of crises swept through the emerging markets in the late 1990s: East Asian economies collapsed, Russia defaulted, and Argentina, Brazil, and Turkey faced severe stress. In response to these problems, emerging markets became far more circumspect about borrowing from abroad to finance domestic demand. Instead, their corporations, governments, and households cut back on investment and reduced consumption. Formerly net absorbers of financial capital from the rest of the world, a number of these countries became net exporters of financial capital. Combined with the savings of habitual exporters such as Germany and Japan, these circumstances created what Chairman Bernanke referred to as a "global saving glut" (Bernanke, 2005).

Clearly, the net financial savings generated in one part of the world must be absorbed by

Raghuram G. Rajan is the Eric Gleacher Distinguished Service Professor of Finance at the Booth School of Business, University of Chicago.

(C) 2009, The Federal Reserve Bank of St. Louis. The views expressed in this article are those of the author(s) and do not necessarily reflect the views of the Federal Reserve System, the Board of Governors, or the regional Federal Reserve Banks. Articles may be reprinted, reproduced, published, distributed, displayed, and transmitted in their entirety if copyright notice, author name(s), and full citation are included. Abstracts, synopses, and other derivative works may be made only with prior written permission of the Federal Reserve Bank of St. Louis. 
deficits elsewhere. Corporations in industrialized countries initially absorbed these savings by expanding investment, especially in information technology, but this proved unsustainable and investment was cut back sharply after the collapse of the information technology bubble.

Extremely accommodative monetary policy by the world's central banks, led by the Federal Reserve, ensured the world did not suffer a deep recession. Instead, the low interest rates in a number of countries ignited demand in interestsensitive sectors such as automobiles and housing. House prices started rising, as did housing investment.

U.S. price growth was by no means the highest. Housing prices reached higher values relative to rent or incomes in Ireland, Spain, the Netherlands, the United Kingdom, and New Zealand, for example. Then why did the crisis first manifest itself in the United States? Probably because the United States went further with financial innovation, thus drawing more buyers with marginal credit quality into the market.

Holding a home mortgage loan directly is very hard for an international investor because it requires servicing, is of uncertain credit quality, and has a high propensity for default. Securitization dealt with some of these concerns. If the mortgage was packaged together with mortgages from other areas, diversification would reduce the risk. Furthermore, the riskiest claims against the package could be sold to those with the capacity to evaluate them and an appetite for bearing the risk, while the safest AAA-rated portions could be held by international investors.

Indeed, because of the demand from international investors for AAA paper, securitization focused on squeezing out the most AAA paper from an underlying package of mortgages: The lower-quality securities issued against the initial package of mortgages were repackaged once again with similar securities from other packages, and a new range of securities, including a large quantity rated AAA, was issued by this "collateralized debt obligation."

The "originate-to-securitize" process had the unintended consequence of reducing the due diligence undertaken by originators. Of course, originators could not completely ignore the true quality of borrowers because they were held responsible for initial defaults, but because house prices were rising steadily over this period, even this source of discipline weakened.

If the buyer could not make even the nominal payments involved on the initial low mortgage teaser rates, the lender could repossess the house, sell it quickly in the hot market, and recoup any losses through the price appreciation. In the liquid housing market, as long as the buyer could scrawl an " $X$ " on the dotted line, he or she could own a home.

The slicing and dicing through repeated securitization of the original package of mortgages created very complicated securities. The problems in valuing these securities were not obvious when house prices were rising and defaults were few. But as house prices stopped rising and defaults started increasing, the valuation of these securities became very complicated.

\section{MALEVOLENT BANKERS OR FOOLISH NAIIFS?}

It was not entirely surprising that bad investments would be made in the housing boom. What was surprising was that the originators of these complex securities-the financial institutions that should have understood the deterioration of the underlying quality of mortgages-held on to so many of the mortgage-backed securities (MBS) in their own portfolios. Simply: Why did the sausage-makers, who knew what was in the sausage, keep so many sausages for personal consumption?

The explanation has to be that at least one arm of the bank thought these securities were worthwhile investments, despite their risk. Investment in MBS seemed to be part of a culture of excessive risk-taking that had overtaken banks. A key factor contributing to this culture is that, over short periods of time, it is very hard, especially in the case of new products, to tell whether a financial manager is generating true excess returns adjusting for risk or whether the current returns are simply compensation for a risk that 
has not yet shown itself but will eventually materialize. Such difficulty could engender excess risk-taking both at the top of and within the firm.

For instance, the performance of CEOs is evaluated in part on the basis of the earnings they generate relative to their peers. To the extent that some leading banks can generate legitimately high returns, this puts pressure on other banks to keep up. CEOs of "follower" banks may take excessive risks to boost various observable measures of performance.

Indeed, even if managers recognize that this type of strategy is not truly value creating, a desire to pump up their bank's stock prices and their own reputations may nevertheless make it their most attractive option. There is anecdotal evidence of such pressure on top management-perhaps most famously from Citigroup chairman, Chuck Prince, in describing why his bank continued financing buyouts despite mounting risks: "When the music stops, in terms of liquidity, things will be complicated. But, as long as the music is playing, you've got to get up and dance. We're still dancing” (Wighton, 2007).

Even if top management wants to maximize long-term bank value, it may be difficult to create incentives and control systems that steer subordinates in this direction. Given the competition for talent, traders have to be paid generously based on performance, but many of the compensation schemes paid for short-term, risk-adjusted performance. This setting gave traders an incentive to take risks that were not recognized by the system, so they could generate income that appeared to stem from their superior abilities, even though it was in fact only a market-risk premium.

The classic case of such behavior is to write insurance on infrequent events such as defaults, assuming what is termed "tail" risk. If traders are allowed to boost bonuses by treating the entire insurance premium as income, instead of setting aside a significant fraction as a reserve for an eventual payout, they have an excessive incentive to engage in this sort of trade.

Indeed, traders who bought AAA-rated MBS were essentially getting the additional spread on these instruments relative to corporate AAA securities (the spread being the insurance premium) while ignoring the additional default risk entailed in these untested securities. The traders in AIG's financial products division took all this to an extreme by writing credit default swaps, pocketing the premiums as bonuses, and not bothering to set aside reserves in case the bonds covered by the swaps actually defaulted.

This is not to say that risk managers in banks were unaware of such incentives. However, they may have been unable to fully control them, because tail risks are by their nature rare and therefore hard to quantify with precision before they occur. Although the managers could try to impose crude limits on the activities of the traders taking maximum risk, these types of trades were likely to have been very profitable (before the risk actually was realized) and any limitations on such profits are unlikely to sit well with a top management that is being pressured for profits.

Finally, all these shaky assets were financed with short-term debt. Why? Because in good times, short-term debt seems relatively cheap compared with long-term capital, and the market is willing to supply it because the costs of illiquidity appear remote. Markets seem to favor a bank capital structure that is heavy on short-term leverage. In bad times, though, the costs of illiquidity seem to be more salient, while risk-averse (and burnt) bankers are unlikely to take on excessive risk. The markets then encourage a capital structure that is heavy on capital. Given the conditions that led banks to hold large quantities of MBS and other risky loans (such as those to private equity financed with a capital structure heavy on short-term debt), the crisis had a certain degree of inevitability.

As house prices stopped rising, and indeed started falling, mortgage defaults started increasing. MBS fell in value and became more difficult to price, and their prices became more volatile. They became hard to borrow against, even over the short term. Banks became illiquid and eventually insolvent. Only heavy intervention has kept the financial system afloat, and though the market seems to believe that the worst is over, its relief may be premature. 


\section{The Blame Game}

Who is to blame for the financial crisis? As my discussion suggests, there are many possible suspects-the exporting countries that still do not understand that their thrift is a burden and not a blessing to the rest of the world; the U.S. households that have spent way beyond their means in recent years; the monetary and fiscal authorities who were excessively ready to intervene to prevent short-term pain, even though they only postponed problems into the future; the bankers who took the upside and left the downside to the taxpayer; the politicians who tried to expand their vote banks by extending homeownership to even those who could not afford it; the markets that tolerated high leverage in the boom only to become risk averse in the bust... The list goes on.

There are plenty of suspects and enough blame to spread. But if all are to blame, should we also not admit they all had a willing accomplice-the euphoria generated by the boom? After all, who is there to stand for stability and against the prosperity and growth in a boom?

Internal risk managers, who repeatedly pointed to risks that never materialized during an upswing, have little credibility and influencethat is, if they still have jobs. It is also very hard for contrarian investors to bet against the boom: As Keynes said, the market can stay irrational longer than investors can stay solvent. Politicians have an incentive to ride the boom, indeed to abet it, through the deregulation sought by bankers. After all, bankers have not only the money to influence legislation but also the moral authority conferred by prosperity.

And what of regulators? When everyone is "for" the boom, how can regulators stand against it? They are reduced to rationalizing why it would be technically impossible for them to stop it.

Everyone is therefore complicit in the crisis because, ultimately, they are aided and abetted by cyclical euphoria. And unless we recognize this, the next crisis will be hard to prevent. For we typically regulate in the midst of a bust when righteous politicians feel the need to do something, when bankers' frail balance sheets and vivid memories make them eschew any risk, and when regulators' backbones are stiffened by public disapproval of past laxity.

\section{THE ROLE OF REGULATION}

We reform under the delusion that the regulated-and the markets they operate in-are static and passive and that the regulatory environment will not vary with the cycle. Ironically, faith in draconian regulation is strongest at the bottom of the cycle-when there is little need for participants to be regulated. By contrast, the misconception that markets will take care of themselves is most widespread at the top of the cycle-the point of maximum danger to the system. We need to acknowledge these differences and enact cycleproof regulation, for a regulation set against the cycle will not stand.

Consider the dangers of ignoring this point. Recent studies such as the Geneva Report (Brunnermeier et al., 2009) have argued for "countercyclical" capital requirements-raising bank capital requirements significantly in good times, while allowing them to fall somewhat in bad times. Although this approach is sensible prima facie, these proposals may be far less effective than intended.

To see why this is so, we need to recognize that in boom times, the market demands very low levels of capital from financial intermediaries, in part because euphoria makes losses seem remote. So when regulated financial intermediaries are forced to hold more costly capital than the market requires, they have an incentive to shift activity to unregulated intermediaries, as did banks in setting up structured investment vehicles and conduits during the current crisis.

\section{Changes in Regulation}

Even if regulations are strengthened to detect and prevent this shift in activity, banks can subvert capital requirements by assuming risk the regulators do not see or do not penalize adequately with capital requirements. Attempts to reduce capital requirements in busts are equally fraught. The risk-averse market wants banks to hold much 
more capital than regulators require, and its will naturally prevails. Even the requirements themselves may not be immune to the cycle. Once memories of the current crisis fade and the ideological cycle turns, the political pressure to soften capital requirements or their enforcement will be enormous.

To have a better chance of creating stability through the cycle-of being cycle-proof-new regulations should be comprehensive, contingent, and cost effective. Regulations that apply comprehensively to all levered financial institutions are less likely to encourage the drift of activities from heavily regulated to lightly regulated institutions over the boom, a source of instability because the damaging consequences of such drift come back to hit the heavily regulated institutions during the bust through channels no one foresees.

Regulations should also be contingent so they have maximum force when the private sector is most likely to do itself harm but bind less the rest of the time. This will make regulations more costeffective, which also makes them less prone to arbitrage or dilution.

Consider some examples of such regulations. First, instead of asking institutions to raise permanent capital, ask them to arrange for capital to be infused when the institution or the system is in trouble. Because these "contingent capital" arrangements will be contracted in good times (when the chances of a downturn seem remote), they will be relatively cheap (compared with raising new capital in the midst of a recession) and thus easier to enforce. Also, because the infusion is seen as an unlikely possibility, firms cannot go out and increase their risks by using the future capital as backing. Finally, because the infusions occur in bad times when capital is really needed, they protect the system and the taxpayer in the right contingencies.

One version of contingent capital is requiring banks to issue debt that would automatically convert to equity when two conditions are met: first, when the system is in crisis, either based on an assessment by regulators or based on objective indicators; and second, when the bank's capital ratio falls below a certain value (Squam Lake Working Group on Financial Regulation, 2009).
The first condition ensures that banks that do badly because of their own idiosyncratic errors, and not when the system is in trouble, do not avoid the disciplinary effects of debt. The second condition rewards well-capitalized banks by allowing them to avoid the forced conversion (the number of shares to which the debt converts will be set at a level to substantially dilute the value of old equity), while also giving banks that anticipate losses an incentive to raise new equity well in advance.

Another version of contingent capital is requiring systemically important levered financial institutions to buy fully collateralized insurance policies (from unlevered institutions, foreigners, or the government) that will infuse capital into these institutions when the system is in trouble (Kashyap, Rajan, and Stein, 2009).

Here is one way this type of system could operate. Megabank would issue capital insurance bonds-say, to sovereign wealth funds-and invest the proceeds in Treasury bonds, which would then be placed in a custodial account in State Street Bank. Every quarter, Megabank would pay a pre-agreed insurance premium (contracted at the time the capital insurance bond is issued) which, together with the interest accumulated on the Treasury bonds held in the custodial account, would be paid to the sovereign fund.

If the aggregate losses of the banking system exceed a certain prespecified amount, Megabank would start receiving a payout from the custodial account to bolster its capital. The sovereign wealth fund would then face losses on the principal it has invested, but on average, it would be compensated by the insurance premium.

Consider regulations aimed at "too big to fail" institutions. Regulations to limit their size and activities will become very onerous when growth is high, thus increasing the incentive to dilute these regulations. Perhaps, instead, a more cyclically sustainable regulation would be to make these institutions easier to close down. What if systemically important financial institutions were required to develop a plan that would enable them to be resolved over a weekend?

Such a "shelf bankruptcy" plan would require banks to track, and document, their exposures 
much more carefully and in a timely manner, probably through much better use of technology. The plan would require periodic stress testing by regulators and the support of enabling legislation-such as facilitating an orderly transfer of a troubled institution's swap books to precommitted partners. Not only would the requirement to develop resolution plans give these institutions the incentive to reduce unnecessary complexity and improve management, it also would not be much more onerous in the boom cycle and might indeed force management to think the unthinkable at such times.

\section{CONCLUSION}

A crisis offers us a rare window of opportunity to implement reforms-it is a terrible thing to waste. The temptation will be to overregulate, as we have done in the past. This creates its own perverse dynamic. For as we start eliminating senseless regulations once the recovery takes hold, we will find deregulation adds so much economic value that it further empowers the deregulatory camp. Eventually, though, the deregulatory momentum will cause us to eliminate regulatory muscle rather than fat. Perhaps rather than swinging maniacally between too much and too little regulation, it would be better to think of cycleproof regulation.

\section{REFERENCES}

Bernanke, Ben S. "The Global Saving Glut and the U.S. Current Account Deficit.” Remarks by Governor Ben S. Bernanke at the Homer Jones Memorial Lecture, St. Louis, Missouri, April 14, 2005; www.federalreserve.gov/boarddocs/speeches/2005/ 20050414/default.htm.

Brunnermeier, Markus K.; Crockett, Andrew; Goodhart, Charles A.; Persaud, Avinash D. and Shin, Hyun Song. The Fundamental Principles of Financial Regulation: Geneva Reports on the World Economy 11. London: Centre for Economic Policy Research, 2009.

Kashyap, Anik K.; Rajan, Raghuram G. and Stein, Jeremy C. "Rethinking Capital Regulation" in Federal Reserve Bank of Kansas City Symposium, Maintaining Stability in a Changing Financial System, February 2009, pp. 431-71; www.kc.frb.org/ publicat/sympos/2008/ KashyapRajanStein.03.12.09.pdf.

Squam Lake Working Group on Financial Regulation. "An Expedited Resolution Mechanism for Distressed Financial Firms: Regulatory Hybrid Securities." Working paper, Council on Foreign Relations, Center for Geoeconomic Studies; April 2009; www.cfr.org/content/publications/attachments/ Squam_Lake_Working_Paper3.pdf.

Wighton, David. "Citigroup Chief Stays Bullish on Buy-Outs.” Financial Times, July 9, 2007; www.ft.com/cms/s/0/80e2987a-2e50-11dc-821c0000779fd2ac.html?nclick_check=1. 